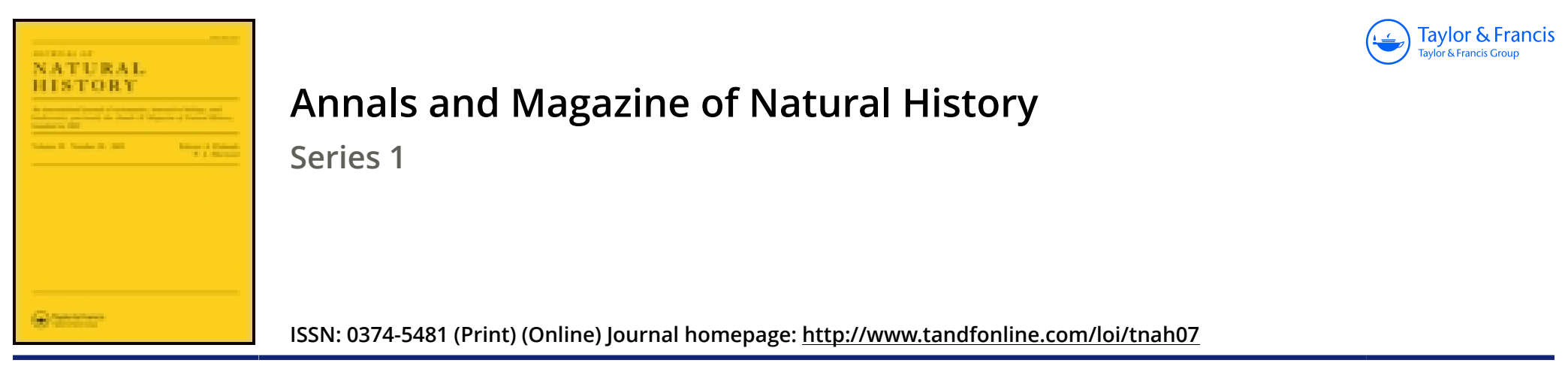

\title{
Description of a new British sponge
}

\section{Dr. Johnston}

To cite this article: Dr. Johnston (1847) Description of a new British sponge, Annals and Magazine of Natural History, 18:122, 475-475, DOI: 10.1080/037454809494463

To link to this article: http://dx.doi.org/10.1080/037454809494463

册Published online: 14 Dec 2009.

Submit your article to this journal 중

Q View related articles $\longleftarrow$ 
colour as the pileus, paler on the lower half, covered with the ochraceous powder or slightly squamulose, the flesh white, yellowish under the epidermis; the portion of stalk within the veil is pale, a very little fibrilose, but not powdered. Diameter of the pileus 3 inches; height of the stem 5 inches, the diameter nearly an inch; breadth of the gills $\frac{2}{10}$ ths. From the woods at Anton's-hill, September 16,1845 .

This truly magnificent agaric was ascertained satisfactorily to be the Agaricus caperatus of 'Fl. Dan.' t. 1675, by the Rev. M. J. Berkeley, to whom a specimen was sent. It is not the $A g$. caperatus of the 'English Flora,' nor the Ag. pudicus of Bulliard; and is a beautiful addition to the already extensive list of British species, for which we are indebted to the researches of Miss Anne Hunter, an honorary member of the Club. The spores, Mr. Berkeley says, are very peculiar. "Its greatest peculiarity," says Miss Anne Hunter, " is its being so profusely covered over its pileus, curtain and stem with a yellowish powder, in such quantities as to make it disagreeable to gather, as gloves and everything it came in contact with was covered. And I am much struck with the toughness and permanency of the curtain, which remains after the pileus has attained its full size."

When small and young the pileus is obtusely campanulate, but in other respects it does not differ from the mature plant. Miss Hunter has found it on one spot only in the wood behind the house of $\mathrm{An}$ ton's-hill, and there sparingly. Like most of its genus it is eaten greedily by slugs and the maggot of a dipterous fly; and it seems to be, says Miss Hunter, " a most favourite food of a sort of beetle," which permits very few specimens to attain maturity without great mutilation.-Fron the Transactions of the Berwickshire Naturalists Clab, vol. ii, p. 174.

\section{Description of a new British Sponge. By Dr. Johnston.}

HaLICHONDRIa maCUlaris.

Sponge forming a thin circular spot one or two lines in thickness, and rather more than an inch in diameter, of a wax-yellow colour, spongeous texture, but not reticular, and soft when recent; the surface even, somewhat hirsute, with pores invisible or scarcely visible to the naked eye, and no fecal orifices. Spicula numerous, long and straight, needle-shaped, smooth; they are all alike in figure and do not much differ in length.

This is amongst the least attractive of its genus. The only species to which it is closely allied is the Halichondria sanguinea, from which it is distinguished by its colour and less fleshy texture, and by the straightness of the spicula. These are remarkable for their length; and the obtuse head is very slightly sinuated a little below the extremity, but it requires a high magnifier to discover this character.

This new species was found spreading, lichen-like, on the inner surface of an old valve of Cyprina islandica, which was brought up, from a depth of about thirty-five fathoms, by the baited lines of our fishermen.-Ibid. p. 196. 